Relations industrielles

Industrial Relations

\title{
Harry ANTONIDES : Renewal in the Workplace : A Critical Look at Collective Bargaining. London, Ontario, Christian Labour Association of Canada, 1982, 82 pp., ISBN 0-919663-00-1
}

\section{Alton W.J. Craig}

Volume 39, numéro 2, 1984

URI : https://id.erudit.org/iderudit/050038ar

DOI : https://doi.org/10.7202/050038ar

Aller au sommaire du numéro

Éditeur(s)

Département des relations industrielles de l'Université Laval

ISSN

0034-379X (imprimé)

1703-8138 (numérique)

Découvrir la revue

Citer ce compte rendu

Craig, A. W. (1984). Compte rendu de [Harry ANTONIDES : Renewal in the Workplace : A Critical Look at Collective Bargaining. London, Ontario, Christian Labour Association of Canada, 1982, 82 pp., ISBN 0-919663-00-1]. Relations industrielles / Industrial Relations, 39(2), 393-394.

https://doi.org/10.7202/050038ar

Tous droits réservés @ Département des relations industrielles de l'Université Laval, 1984
Ce document est protégé par la loi sur le droit d'auteur. L'utilisation des services d’Érudit (y compris la reproduction) est assujettie à sa politique d'utilisation que vous pouvez consulter en ligne.

https://apropos.erudit.org/fr/usagers/politique-dutilisation/ 
they structural or technical (p. 84). It is a great task of management to synchronize both work changes and human changes in order to achieve a perfect mutual reinforcement in this respect.

The papers on comparative assessments and evaluation (Bartolke and Gohl, Hepworth and Osbaldeston) ask some major questions: how much of a genuine concern for the welfare of workers is involved in the QWL projects? Which among the various approaches to QWL are generally successful and which lead to problems or even failures? As long as the management's primarily motivation are profits and earnings, welfare and workers (as well as clients) remain of a secondary importance.

A management belief in the legitimacy of worker participation is an important factor of the QWL success. A tight labour market makes management more favourably oriented. The 'project' team system in which employee groups are set up to solve particular problems seems to be much promising.

The immediate supervisors are particularly vulnerable and it is necessary to pay a particular attention to their changing roles. The wage payment systems have to be adequately redesigned in order to secure for the employees an appropriate reward for a higher performance. There is also a need for education towards a broader interpretation of promotion. A relevant information has to be provided, as well as enough additional training.

The organizational aspects of work humanisation are well presented in this book which should become well accepted by the interested readers.

Alexander J. MATEJKO

University of Alberta
Renewal in the Workplace: A Critical Look at Collective Bargaining, by Harry Antonides, London, Ontario, Christian Labour Association of Canada, 1982, 82 pp., ISBN 0-919663-00-1

In this short booklet, Mr. Antonides, research director for the Christian Labour Association of Canada (CLRA), briefly examines man's relationship to God and its ramifications for such issues as the nature of work, quality of worklife, codetermination, inflation, strikes, compulsory arbitration and union plurality. On the basis of a rather superficial analysis of these issues as seen from a Christian perspective, the author recommends solutions to a variety of problems which he sees as part of the malaise of the Canadian industrial relations system.

The sections which discuss man's relationship to God are developed in a rather cursory way with man being viewed as the image bearer of God with one of his tasks as the keeper and developer of God's creation. The author acknowledges that the Christian faith does not provide quick and easy answers to immediate problems, and that Christians possess no magic formulas. Nevertheless, he makes some very specific recommendations on some very complex issues.

After describing how work has been broken down into small parts which are often routine and boring, he endorses the concept of quality of worklife projects without showing how this will change the meaning of work from a Christian perspective. While being critical of the hierarchical structure of organizations and the lack of worker participation in the decision-making process, the author recommends a form of codetermination (workers elected to the boards of directors) which is practised in a number of European countries, but he does not show how this conforms to the Christian view of man.

Inflation is seen as a cruel form of income redistribution and its major cause is seen as greed - a greed that lives inside of us. While the author acknowledges that greed 
cannot be legislated away, he proposes that some form of wage and price restraints be reinstated with higher increases being allowed for lower income groups than for higher income group. However, he does not mention the administrative nightmare that would be caused by such a program, nor does he propose the extent to which the income differential between high and low income earners should be decreased. In addition, the author argues that the everyone-for-himself approach which now dominates collective bargaining be replaced by a concensus-oriented one in which the country as a whole would benefit. One wonders whether the author is aware of the very substantial difficulties that exist in obtaining such a national concensus in Canada's extremely decentralized collective bargaining structure.

It is asserted that labour relations are aggravated because employers and employees view each other as adversaries, and their relationship is said to be governed by the concept of power. The author attacks the adversary approach and says that his booklet's main theme is that work expresses something of the image of God in man. "One of the implications of this perspective is that labour and management are not seen as adversaries but as partners in a joint undertaking» (p. 61). The above conclusion cannot logically be drawn from what is contained in this booklet. Perhaps the author has not elaborated sufficiently on the fundamentals of the Christian perspective to provide the necessary underpinnings for his conclusion.

The author calls for compulsory arbitration in essential services such as those provided by hospital workers, firemen and policemen. In fact, compulsory arbitration now applies to firemen and policemen across Canada, with the exception of municipal workers in New Brunswick and Nova Scotia. However, hospital workers are not covered by arbitration all across the country. The author argues that arbitration boards should be instructed that wage rates for workers under compulsory arbitration should not fall behind those of other workers. It is easy to agree with this proposal, but difficulties arise when one asks which other workers should be used as a reference group.

In attacking any form of compulsory unionism, and particularly in the construction industry, the author argues that a plurality of unions would be a fair solution. What appears to be the central issue here is the idea of one union being the exclusive bargaining agent for the members of a defined bargaining unit plus all forms of union dues which force workers to support one particular union. While the author argues that freeloading could be a problem if members were not required to pay union dues, he states that the CLAC has got around the problem of all dues going to one union by allowing workers who support another union to have their dues sent to the union of their choice. It is unclear as to what benefits, if any, these other unions provide to these workers.

The foregoing issues are the main ones discussed in the booklet under review. Given the number of issues discussed and the limited space devote to each issue, the discussions are all too brief. Conclusions are arrived at without a logical, sequential discussion.

Anyone who has read any or all of the Papal Encyclicals dealing with labour problems will find the present work very inadequate as an expression of the Christian message on unionism and collective bargaining. Also, the author draws conclusions which are not sufficiently supported by the Christian message he presents. In fact, the conclusions reached in this booklet could be drawn without any reference to the biblical message. Anyone who is looking for the implications of the Christian message for unionism and collective bargaining in this booklet will be sadly disappointed.

Alton W.J. CRAIG

University of Ottawa 